\title{
Myrtaceae dos campos de altitude do Parque Nacional do Caparaó - Espírito Santo/Minas Gerais, Brasil
}

\author{
Fiorella Fernanda Mazine $e^{1,2}$ \& Vinicius Castro Souza ${ }^{1}$
}

\begin{abstract}
Resumo
(Myrtaceae dos campos de altitude do Parque Nacional do Caparaó - Espírito Santo/Minas Gerais, Brasil) O presente trabalho visa a identificação e caracterização das espécies de Myrtaceae ocorrentes nos campos de altitude do Parque Nacional do Caparaó, localizado na divisa dos estados de Minas Gerais e Espírito Santo, sendo sua vegetação formada por florestas e campos de altitude. Apresenta em geral altitudes em torno de $2.000 \mathrm{~m}$, sendo seu ponto culminante o Pico da Bandeira, com 2.890 metros, representando o ponto de maior altitude da Região Sudeste. Myrtaceae está representada na área por 10 espécies, pertencentes a seis gêneros: Blepharocalyx salicifolius, Gomidesia affinis, Gomidesia clausseniana, Marlierea angustifolia, Myrceugenia alpigena, Myrceugenia ovata, Myrcia obovata, Myrcia subcordata, Myrcia venulosa e Pimenta pseudocaryophyllus.

Palavras-chave: Blepharocalyx, Gomidesia, Marlierea, Myrceugenia, Myrcia, Pimenta, Pico da Bandeira.
\end{abstract}

Abstract

(Myrtaceae of the Highlands of Parque Nacional do Caparaó - Espírito Santo/Minas Gerais, Brazil) This work aims identify and characterize species of Myrtaceae occurring in the highlands of the Parque Nacional do Caparaó, between Minas Gerais and Espírito Santo states. The vegetation in the area comprises forests and 'campos de altitude', occurring at around $2000 \mathrm{~m}$, and the highest peak is the Pico da Bandeira, the highest point in the Southeastern region, with $2890 \mathrm{~m}$. Myrtaceae is represented in that area by six genera and a total of ten species: Blepharocalyx salicifolius, Gomidesia affinis, Gomidesia clausseniana, Marlierea angustifolia, Myrceugenia alpigena, Myrceugenia ovata, Myrcia obovata, Myrcia subcordata, Myrcia venulosa and Pimenta pseudocaryophyllus.

Key words: Blepharocalyx, Gomidesia, Marlierea, Myrceugenia, Myrcia, Pimenta, Pico da Bandeira.

\section{INTRODUÇÃO}

Myrtaceae constitui-se em uma família com cerca de 3.000 (Kawasaki \& Holst 2004) a 5.800 (Lughadha \& Snow 2000) espécies, subordinadas a cerca de 100 gêneros (Landrum \& Kawasaki 1997; Kawasaki \& Holst 2004), apresentando ampla distribuição pelo globo, mas preferencialmente distribuídas pelas zonas tropicais e subtropicais (Barroso et al. 1984; Legrand \& Klein 1978). É uma das mais importantes famílias no Brasil, sendo freqüentemente uma das famílias lenhosas dominantes em diversas formações naturais, particularmente na Mata Atlântica (Barroso \& Peron 1994; Leitão-Filho 1993; Reitz et al. 1978). No Brasil, estima-se que ocorram aproximadamente 1.000 espécies e 19 gêneros (Landrum \& Kawasaki 1997).

Com o estudo iniciado para a Flora do Parque Nacional do Caparaó, Leoni (1997) citou numa listagem preliminar de fanerógamas a ocorrência de 12 espécies de Myrtaceae, incluindo espécies florestais e campestres.

O principal objetivo deste trabalho foi realizar o levantamento de Myrtaceae dos campos de altitude do Parque Nacional do Caparaó, apresentando descrições, ilustrações e chaves analíticas de identificação para as espécies ocorrentes na área de estudo, bem como análises e comentários sobre a variabilidade morfológica e taxonomia para essas espécies, contribuindo assim para o melhor conhecimento da flora do Parque Nacional do Caparaó.

\section{Material e Métodos}

Situado em uma das maiores altitudes da Região Sudeste, entre as coordenadas $20^{\circ} 19^{\prime}-$ $20^{\circ} 37^{\prime}$ 'S e 41 $43^{\circ}-41^{\circ} 53^{\prime} \mathrm{W}$, o Parque Nacional do Caparaó localiza-se na divisa dos estados de Minas Gerais e Espírito Santo, incluindo os municípios de Alto Caparaó, Alto Jequitibá, Divino, EsperaFeliz, Manhuaçu, Presidente Soares, Lajinha

Artigo recebido em 03/2007. Aceito para publicação em 10/2007.

${ }^{1}$ ESALQ/USP, Herbário ESA, Av. Pádua Dias, 11, C.P. 9, 13418-900, Piracicaba, SP, Brasil.

${ }^{2}$ Bolsista CAPES; ffmazine@ carpa.ciagri.usp.br 
(MG) e Alegre, Divino de São Lourenço, Dores do Rio Preto, Iúna, Irupi, Ibitirama (ES), com aproximadamente $70 \%$ das terras do Parque concentradas no Espírito Santo. O Parque apresenta em sua maior extensão, altitudes em torno de 2.000 metros, sendo que o seu pico culminante é o da Bandeira com 2.890 metros.

Vários são os fatores ligados às condições físicas, climáticas e antrópicas que determinaram os tipos de vegetação encontrados no Parque Nacional do Caparaó. De acordo com o IBDF (1981) a região é ocupada por Floresta Estacional Semidecidual (Floresta Subcaducifólia Estacional) em Minas Gerais, Floresta Ombrófila Densa (Floresta Pluvial Tropical) na porção do Espírito Santo, havendo formação de campos nos pontos de maior altitude.

Os campos de altitude em geral surgem acima de $2.000 \mathrm{~m}$, compreendendo uma flora característica e diversificada, incluindo muitas espécies endêmicas (Leoni \& Souza 1999). Nos campos de altitudeo estrato herbáceoé contínuo, predominando Asteraceae, Bromeliaceae, Droseraceae, Orchidaceae, Oxalidaceae, Polygalaceae e Poaceae (Leoni 1997). Arbustos esparsos são também comuns com destaque para espécies de Asteraceae, Ericaceae, Melastomataceae, Myrtaceae e Scrophulariaceae (Leoni 1997).

O levantamento das espécies de Myrtaceae ocorrentes nos campos de altitude do Parque Nacional do Caparaó foi baseado em consultas bibliográficas, consultas aos herbários em que existe maior concentração de espécimes coletados no Parque (BHCB, CESJ, ESA, GFJP, HB, R, RB), observações de campo e coletas. Os herbários são citados de acordo com Holmgren et al. (1990).

Na citação do Material examinado foram referidos todos os materiais coletados na área de estudo. Na sequiência, foram listados os provenientes de outras localidades e citados como Material adicional selecionado. Vale ressaltar que os materiais do Parque referidos como Material adicional selecionado são aqueles não coletados em campos de altitude.

A distribuição geográfica das espécies foi baseada no material examinado e complementada, quando possível, com dados de literatura.

\section{Resultados e Discussão}

Myrtaceae Juss., Gen. P1. 322. 1789. (Caracterização morfológica da família baseada em Barroso et al. 1984; Cronquist 1981; Heywood 1979; Hickey \& King 1988; Holst et al. 2003; Kawasaki 2000; Kawasaki \& Holst 2004; Legrand \& Klein 1978)

Plantas arbustivas ou arbóreas, com córtex que pode ou não esfoliar-se, glabras ou com indumento de tricomas simples ou dibraquiados, unicelulares, raramente escamoso. Canais oleíferos, presentes na forma de pequenos pontos translúcidos, evidentes nas folhas, flores, frutos e sementes. Folhas simples, geralmente coriáceas, inteiras, opostas ou alternas, geralmente peninérveas; nervuras laterais unidas na sua extremidade por meio de uma nervura marginal ou formando arcos. Inflorescências cimosas ou racemosas ou raramente flores solitárias. Flores comumente bibracteoladas na base, hermafroditas, actinomorfas, diclamídeas, dialipétalas, raramente com pétalas de tamanho reduzido ou abortadas; hipanto formado pela parede do receptáculo floral, que pode ser infundibuliforme, globoso, anguloso ou liso, prolongado ou não acima do ovário; sépalas (3-)4-5(-6), iguais ou desiguais entre si, imbricadas, ou cálice às vezes indiviso nos botões e rasgando irregularmente ou decíduo como uma caliptra, ou reduzido; pétalas (3-) 4-5(-6), livres, imbricadas, às vezes coniventes formando uma caliptra, ou às vezes faltando, geralmente brancas, raramente rosadas ou azuladas; androceu polistêmone, estames livres entre si, originados numa sequiência centrípeta, com filetes filiformes, livres ou parcialmente conatos, anteras bitecas, globosas, rimosas; ovário gamocarpelar, ínfero, com número variável de lóculos e óvulos; placentação geralmente axial, raramente parietal; estilete terminal, geralmente alongado, com estigma capitado, raramente séssil ou lobado; óvulos 2-muitos por lóculo. Fruto do tipo baga, cápsula loculicida, ou às vezes drupa ou noz; mesocarpo carnoso ou suculento. Sementes 1-muitas, com pouco ou comumente sem endosperma; cotilédones pequenos a grandes; hipocótilo pequeno a alongado.

Nos campos de altitude do Parque Nacional do Caparaó foram registradas 10 espécies de Myrtaceae, subordinadas a seis gêneros. 
Chave para identificação dos gêneros

(Adaptada de Landrum \& Kawasaki (1997) para as espécies coletadas na área de estudo)

1. Cálice quase totalmente fechado no botão rompendo-se em 4 sépalas irregulares durante a antese; fruto geralmente coroado por remanescentes do cálice Marlierea

1'. Cálice aberto no botão com 4 ou 5 lobos claramente distintos e regulares e geralmente persistentes; fruto coroado pelos lobos do cálice ou por uma cicatriz quadrangular.

2. Cálice 4-mero.

3. Cálice caindo na antese, deixando uma cicatriz quadrangular no fruto ... Blepharocalyx

3'. Cálice persistente.

4. Flores solitárias, geralmente duas por nó foliar, axilares, embrião mircióide ........ Myrceugenia

4'. Flores arranjadas em dicásios ou panículas de 3-15 flores; embrião mirtóide ... Pimenta

2'. Cálice 5-mero.

5. Anteras com sacos polínicos de cada teca dispostos em alturas diferentes ...... Gomidesia

5'. Anteras com sacos polínicos de cada teca dispostos na mesma altura ........ Myrcia

Blepharocalyx O. Berg, Linnaea, 27: 412. 1856.

Arbustos ou árvores, tricomas simples ou simétrica a assimetricamente dibraquiados. Dicásios de 3 a 15 flores ou panícula com unidades dicasiais, raramente inflorescências unifloras. Cálice aberto ou fechado no botão, 4-mero, geralmente decíduo na antese; bractéolas decíduas; hipanto ligeiramente prolongado acima do ovário; anteras com deiscência longitudinal; ovário 2-locular, com 4-17 óvulos por lóculo, placentação axilar. Bagas globosas, coroadas por uma cicatriz quadrangular; sementes $1-15$, reniformes, com testa membranácea a cartilaginosa; embrião mirtóide.

Atualmente são reconhecidas três espécies de Blepharocalyx (Landrum 1986), que distribuem-se do norte ao sul da América do Sul (Equador, Venezuela, Bolívia, Chile, Uruguai, Paraguai, Brasil e norte da Argentina). No Brasil, ocorrem apenas duas espécies, sendo uma amazônica e outra extra-amazônica.

1. Blepharocalyx salicifolius (Kunth) O. Berg, Linnaea 27: 413. $1856 . \quad$ Fig. $1 \mathrm{c}-\mathrm{f}$

Arbusto ca. $1 \mathrm{~m}$ alt., ramos jovens densamente pubescente-tomentosos, ramos adultos esparsamente pubérulos, tricomas alvos. Folhascom pecíolo de 1-2 mm compr.; lâminas concolores, oval-lanceoladas ou elípticas, $0,9-1,7 \times 3-7 \mathrm{~mm}$, coriáceas, glabras a esparsamente pubescentes em ambas as faces; ápice agudo a agudo-acuminado; base aguda a arredondada; margem revoluta; nervura central sulcada a saliente na face adaxial e saliente na face abaxial; nervuras secundárias em número de 6-9 pares, salientes em ambas as faces; nervura marginal simples, a menos de $0,5 \mathrm{~mm}$ da margem; pontuações evidentemente salientes em ambas as faces. Dicásios, raramente flores solitárias, axilares, pedúnculo5-10 mm compr., subglabro a densamente pubescente. Botões 2-3 mm compr., esparsa a densamente pubescentes, sendo o hipanto densamente pubescente; bractéolas ca. 1 mm compr., lineares, decíduas na antese; cálice aberto no botão; sépalas suborbiculares a triangulares, esparsa a densamente pubescentes, às vezes com margem ciliada; ovário 2-locular. Bagas globosas, 3-6 mm, glabras a esparsamente pubérulas, alaranjadas; superfície lisa.

Distribuição geográfica: segundo Landrum (1986), B. salicifolius ocorre no Equador, Bolívia, Brasil, Paraguai, Argentina e Uruguai. No Brasil, distribui-se desde Goiás e Minas Gerais até o Rio Grande do Sul (Landrum 1986). Dubs (1998) referiu, ainda, que a espécie ocorre no estado de Mato Grosso do Sul. No Parque, foi encontrada apenas nos campos de altitude.

Material examinado: BRASIL. MINAS GERAIS: Alto Caparaó, Parque Nacional do Caparaó, 19.XI.1988, bt., L. Krieger etal. s.n. (CESJ 23097, ESA); s/município, 2.VII.1888, fr., W. Schwacke s.n. (R 25249); s/município, 6.IX.1977, fl. ebt., G J. Shepherd et al. 5789 (R, UEC).

Blepharocalyx salicifolius é uma árvore atrativa que é freqüentemente cultivada no Brasil, 
Argentina e Uruguai; as flores são agradavelmente aromáticas e as folhas são usadas medicinalmente em chás (Landrum 1986). Landrum \& Kawasaki (1997) citaram que B. salicifolius é uma espécie extremamente variável.

Gomidesia O. Berg, Linnaea 27: 6. 1855.

Arbustos ou árvores. Cimeiras ou panículas. Cálice aberto no botão; sépalas 5, geralmente persistentes; bractéolas decíduas; hipanto pouco prolongado sobre o ovário; anteras com os sacos polínicos de cada teca dispostos em alturas diferentes, deiscência longitudinal, margens das tecas encurvadas, simulando linha de deiscência sigmóide, raramente anteras completamente 4-loculares; ovário geralmente 2-locular, com 2 óvulos por lóculo; placentação axilar. Bagas com cálice geralmente persistente; sementes $1(-3)$ com testa cartilaginosa; embrião mircióide.

Legrand (1958) reconheceu 43 espécies para o gênero que se distribuem principalmente no Brasil. Algumas destas são referidas também para Argentina, Uruguai, Paraguai, Venezuela, Guianas, Porto Rico e Cuba. No Brasil, a maioria das espécies concentra-se nas Regiões Sul e Sudeste, raramente chegando até a Bahia e Alagoas.

\section{Chave para identificação das espécies de Gomidesia}

1. Folhas com lâmina 9-12,7 ×3-5 cm, glabras a muito esparsamente pubérulas na face adaxial e pubérulas a pubescentes na face abaxial; bagas 0,9-1,1 cm diâm., esparsamente pubescentes (densamente no ápice) G. affinis

1'. Folhas com lâmina $1-2,5 \times 0,4-1,3 \mathrm{~cm}$, glabras a densamente vilosas em ambas as faces; bagas $0,4-1 \mathrm{~cm}$ diâm., densamente tomentosas a vilosas G. clausseniana

2. Gomidesia affinis (Cambess.) D. Legrand, Notul. Syst. (Paris) 15: 260. 1958. Fig. $2 \mathrm{f}$

Arbustos ca. $3 \mathrm{~m}$ alt., ramos densamente pubescentes, indumento avermelhado. Folhas com pecíolo de 3-7 mm compr.; lâminas discolores, elíptico-oblongas, 9-12,7×3-5 cm, cartáceas, glabras a muito esparsamente pubérulas na face adaxial e pubérulas a pubescentes na face abaxial, tricomas avermelhados; ápice agudo e apiculado; base obtusa; margem inteira, revoluta; nervura central sulcada na face adaxial e saliente na face abaxial; nervuras secundárias em número de 8-13 pares, evidentemente impressas na face adaxial e salientes na face abaxial; nervura marginal simples, a 4-7 mm da margem; pontuações geralmente indistintas em ambas as faces, às vezes distintas e planas na face adaxial. Panículas multifloras, axilares ou subterminais; botões sésseis, 4-5 mm compr., vilosos; bractéolas ovallanceoladas; sépalas tomentosas em ambas as faces, rotundas ou curta a largamente oval-triangulares; ovário 2-locular. Bagas globosas, 0,9-1,1 cm diâm., esparsamente pubescentes (densamente no ápice); amarelas ou vermelhas, com superfície lisa, à vezes com algumas glândulas salientes.
Distribuição geográfica: ocorre desde Minas Gerais e Rio de Janeiro até o Rio Grande do Sul (Legrand 1958; Legrand \& Klein 1967). No Parque Nacional do Caparaó, o único exemplar dessa espécie foi coletado na região do "Córrego do Inácio", área predominantemente ocupada por campos de altitude.

Material examinado: BRASIL: MINAS GERAIS: Alto Caparaó, Parque Nacional do Caparaó, 17.XII.1988, fr., L. Krieger et al. s.n. (CESJ 23323,ESA). Material adicional: BRASIL: MINAS GERAIS: Poços de Caldas, 17.I.1981, fr., S. C. Pereira 847 (UEC). PARANÁ: Teixeira Soares, 8.III.1990, fl., $J$. M. Silva UEC 56858 (UEC); Paranaguá, 24.III.1993, bt. e fl., J. M. Silva \& E. Barbosa 1238 (ESA, MBM). SÃO PAULO: Campinas, 18.II.1997, bt., fl., K. Santos 205 (UEC); 28.III.1997, bt., K. Santos 216 (UEC).

Segundo Legrand \& Klein (1967), a cor "marrom" da face abaxial das folhas, com os tricomas bem desenvolvidos e a aspereza são sem dúvida algumas das características mais evidentes desta espécie. Legrand \& Klein (1967) citou ainda que as folhas de Gomidesia affinis são subvilosas na face abaxial. Já, as folhas do material em questão variam de pubérulas a pubescentes na face abaxial. 


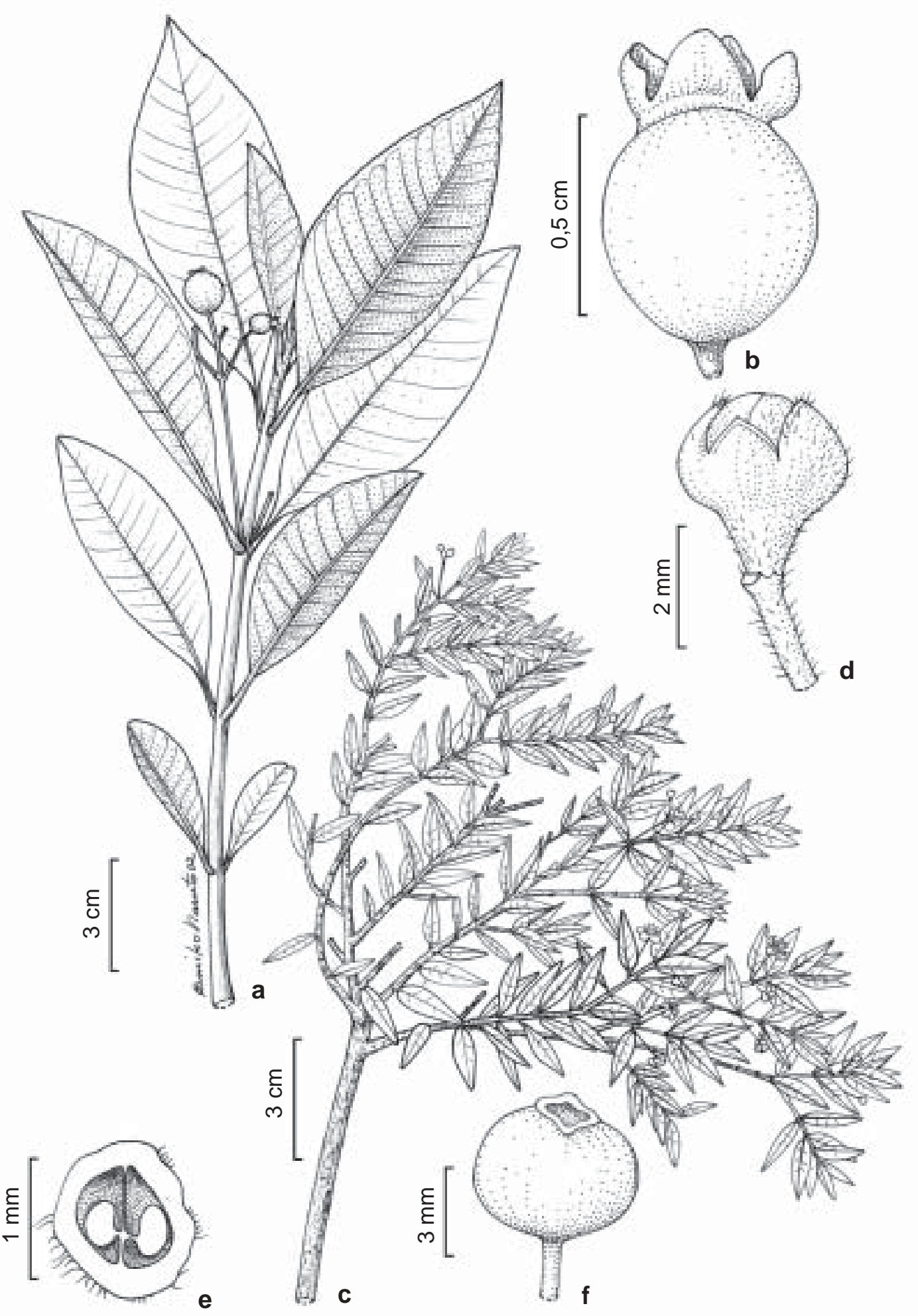

Figura 1 - a-b. Pimenta pseudocaryophyllus - a. ramo com frutos; b- fruto. c-f. Blepharocalyx salicifolius - c. ramo com flores; d. botão floral; e. ovário em corte transversal; f. fruto. (a-b Brade 16942; c-e Shepherd 5789; f Schwacke s.n. R 25249) 
3. Gomidesia clausseniana $\mathrm{O}$. Berg, in Martius, Fl. bras. 14(1): 23. $1857 . \quad$ Fig. 2 a-e

Arbustos 0,5-1,5 m alt., ramos pubescentes a muito densamente vilosos, indumento alvo, avermelhado ou escuro. Folhas com pecíolo de 2-3 mm compr.; lâminas discolores, elípticas a elíptico-oblongas, $1-2,5 \times 0,4-1,3 \mathrm{~cm}$, coriáceas, glabras a densamente vilosas em ambas as faces; ápice agudo, obtuso ou arredondado; base obtusa ou arredondada; margem fortemente revoluta; nervura central sulcada na face adaxial e saliente na face abaxial; nervuras secundárias em número de 9-13 pares, impressas na face adaxial e salientes na face abaxial; nervura marginal simples, a $0,5 \mathrm{~mm}$ da margem; pontuações indistintas ou planas na face adaxial e salientes na face abaxial. Cimeiras axilares, com 3 a 5 flores, pedúnculo 0,7-2,3 cm, densamente tomentoso. Botões 4-5 mm, densamente vilosos; bractéolas 2-3 mm compr., lanceoladas, decíduas; sépalas 1,5-2 $\mathrm{mm}$ compr, triangulares, com ápice acuminado, muito densamente pubescentes a tomentosas; ovário 2-locular. Bagas globosas, 0,4-1 cm diâm., densamente tomentosas a vilosas, tornando-se vináceas, azuis, arroxeadas, avermelhadas e negras com a maturação, lisas. Distribuição geográfica: ocorre em Minas Gerais e Rio de Janeiro (Legrand 1958). No Parque Nacional do Caparaó, foi encontrada nos campos de altitude na trilha para o Pico da Bandeira, na região do Arrozal e em área de floresta no Vale Encantado, à beira de curso d'água. Esta é a primeira citação dessa espécie para o Espírito Santo.

Material examinado: BRASIL. ESPÍRITO SANTO: Iúna, Parque Nacional do Caparaó, 17.II.2000, fl., V. C. Souza et al. 23311 (CESJ, ESA, GFJP); 18.II.2000, fr., V. C. Souza et al. 23334 (CESJ, ESA, GFJP); 18.II.2000, fl., V. C. Souza et al. 23394 (ESA); 18.II.2000, fl., V. C. Souza et al. 23325 (ESA, GFJP); 18.II.2000, fl., V. C. Souza et al. 23335 (CESJ, ESA, GFJP); 18.II.2000, fl., V. C. Souza et al. 23327 (ESA); 18.II.2000, fl., V. C. Souza et al. 23400 (CESJ, ESA, GFJP); 18.II.2000, fl., V. C. Souza et al. 23343 (ESA, GFJP); 18.II.2000, fl., V. C. Souza et al. 23329 (ESA); 18.II.2000, fl., V. C. Souza et al. 23379 (CESJ, ESA, GFJP). s/ município, 9.I.1999, fl., L.S. Leoni 4094 (ESA, GFJP). MINAS GERAIS: Alto Caparaó,
Parque Nacional do Caparaó, VI.1999, fl., L. S. Leoni 4224 (ESA, GFJP); 2.IX.1996, fr., V. C. Souza et al. 12150 (ESA, GFJP, ICN); 2.IX.1996, fr., V. C. Souza et al. 12198 (ESA, GFJP, ICN); 12.II.1998, fl., J. P. Souza et al. 2121 (ESA, GFJP, ICN); 14.X.1998, fl., L. S. Leoni 4043 (ESA, GFJP); 20.X.1999, fr., F. F. Mazine et al. 215 (ESA); XI.1999, fl., L. S. Leoni 4278 (ESA, GFJP); 18.II.2000, fl., V.C. Souza et al. 23320 (CESJ, ESA, GFJP); 19.II.2000, fr., V. C. Souza et al. 23483 (CESJ, ESA, GFJP); 19.II.2000, fr., V. C. Souza et al. 23484 (CESJ, ESA, GFJP); s/município, "Serra do Caparaó", 25.IX.1941, fl., A. C. Brade 17015 (RB); 15.XI.1960, B. Flaster 8(HB).

Material adicional: BRASIL. MINAS GERAIS: Alto Caparaó, Parque Nacional do Caparaó, I.1998, fl., $L$. S. Leoni 3860 (ESA, GFJP); 17.VIII.1999, fr., F. F. Mazine et al. 153 (ESA, ICN); 17.VIII.1999, fr., F. F. Mazine et al. 154 (ESA); 20.X.1999, fr., F. F. Mazine et al. 212 (ESA).

Esta é uma espécie bastante comum nos campos de altitude do Parque. Possui frutos com indumento muito denso, o que confere a eles uma coloração mais clara quando maduros.

Gomidesia clausseniana pertence ao grupo caracterizado por Berg (1857), por possuir folhas pequenas e sépalas acuminadas. As principais características que diferenciam G. clausseniana das demais espécies do grupo são as bractéolas lanceoladas, inflorescências com 3 a 5 flores, além das pequenas dimensões $(1-2,5 \times 0,4-1,3 \mathrm{~cm})$ das folhas.

Marlierea Cambess., in Saint-Hilaire, Fl. Bras. Merid. 2: 373. 1832.

Arbustos ou árvores, tricomas simples ou dibraquiados. Panículas ou cimeiras, raramente pedúnculos paucifloros. Cálice fechado ou quase fechado no botão ou aberto por um pequeno poro, botões florais geralmente apiculados, ou 4-5-denteados no ápice, rompendo-se durante a antese em 4-5 sépalas irregulares, geralmente decíduas; bractéolas persistentes ou decíduas; hipanto elevado sobre o ovário; anteras com deiscência longitudinal; ovário 2(-3) locular, com 2 óvulos em cada lóculo; placentação axilar. Bagas com cálice geralmente não persistente, coroadas por uma cicatriz circular ou remanescentes do cálice; sementes 1-2, com testa cartilaginosa; embrião mircióide. 


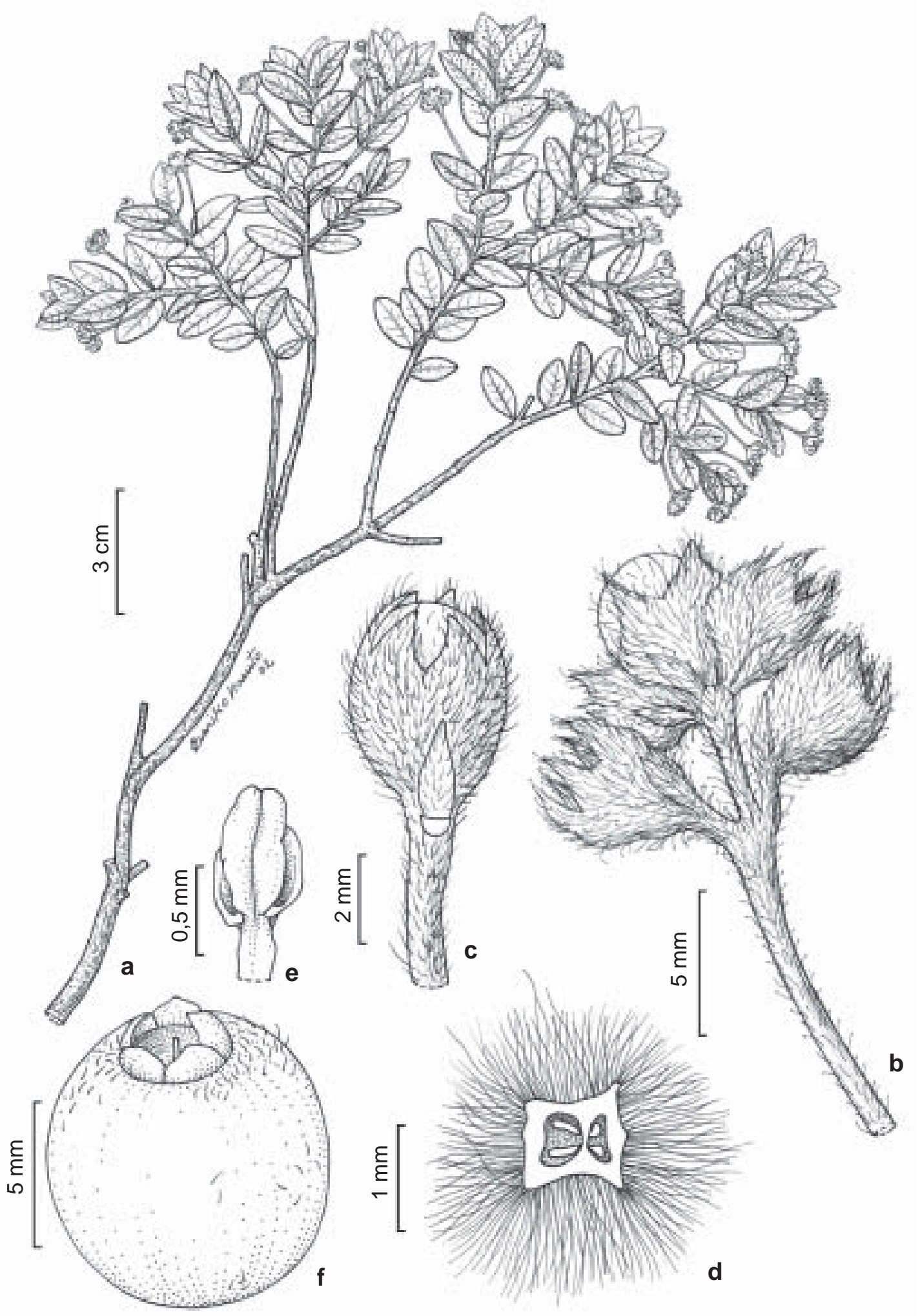

Figura 2 - a-e. Gomidesia clausseniana - a. ramo com flores; b. inflorescência; c. botão floral; d. ovário em corte tranversal; e. antera. f. G. affinis - f. fruto. (a-b Leoni 4094; c-e Souza 23335; f Krieger s.n. CESJ 23323) 
O gênero compreende aproximadamente 95 espécies (Barroso \& Peixoto 1995), distribuídas nas Américas Central e do Sul. A maioria destas concentra-se no Brasil, especialmente nas Regiões Sul, Sudeste e Centro-Oeste (Legrand 1962; McVaugh 1968; Kawasaki 1984; Barroso \& Peixoto 1995).

4. Marlierea angustifolia (O. Berg) Mattos, Ci. \& Cult. 19: 333. 1967. Fig. 3

Arbustos 0,8-3 m alt., ramos geralmente glabros, às vezes pubérulos quando jovens. Folhas com pecíolo de 1-2 mm compr.; lâminas concolores, elíptico-oblongas ou obovais, 1-1,9 $\times 0,3-0,6 \mathrm{~cm}$, cartáceas, glabras na face adaxial e glabras a pubescentes na face abaxial; ápice arredondado; base aguda; margem plana; nervura central sulcada na face adaxial e saliente na face abaxial, nervuras secundárias em número de 8-16 pares, indistintas na face adaxial e salientes na face abaxial; nervura simples ou dupla, a $0,5 \mathrm{~mm}$ da margem; pontuações impressas ou planas na face adaxial e salientes na face abaxial. Cimeiras 2-3-floras, flores solitárias ou em fascículos axilares de até 3-flores; pedúnculo 3-5 mm compr., glabro. Botões ca. $3 \mathrm{~mm}$ compr., glabros; sépalas 4 , desiguais; ovário 2-locular; bractéolas não vistas. Bagas globosas, 0,5-1,2 cm diâm., glabras, vináceas, coroadas por remanescentes do cálice, lisas, às vezes com glândulas salientes.

Distribuição geográfica: ocorre em Minas Gerais (Berg 1857) e em São Paulo (Mattos 1967). No Parque Nacional do Caparaó, todos os exemplares de Marlierea angustifolia foram coletados em locais próximos a cursos d'água. Material examinado: BRASIL. MINAS GERAIS: Alto Caparaó, Parque Nacional do Caparaó, 8.VIII.1999, fr., L. S. Leoni 4235 (ESA, GFJP); 16.II.2000, fl., V. C. Souza et al. 23229 (CESJ, ESA, GFJP).

Material adicional: BRASIL. MINAS GERAIS: Alto Caparaó, Parque Nacional do Caparaó, 18.IX.1988, fr., L. Krieger et al. FPNC 0231 (CESJ); 23.VII.1998, fr., L. S. Leoni 3987 (ESA, GFJP); 17.VIII.1999, fr., F. F. Mazine et al. 152 (ESA, ICN); 17.VIII.1999, fr., F. F. Mazine et al. 156 (ESA, ICN); 17.VIII.1999, fr., F. F. Mazine et al. 157 (ESA, ICN); 17.VIII.1999, bt. e fr., F. F. Mazine et al. 158 (ESA, ICN); 20.X.1999, bt., F.
F. Mazine et al. 213 (ESA); 20.X.1999, fr., F. F. Mazine et al. 221 (ESA).

Marlierea angustifolia caracteriza-se principalmente pelas suas folhas com pequenas dimensões, além de suas flores solitárias, dispostas em cimeiras 2-3-floras ou em fascículos com até 3 flores, ao passo que a grande maioria das espécies do gênero possuem folhas com grandes dimensões e flores em panículas.

Myrceugenia O. Berg, Linnaea 27: 131. 1856.

Arbustos ou árvores; tricomas geralmente dibraquiados. Folhas discolores, freqüentemente apiculadas. Flores geralmente pediceladas, solitárias ou em grupos de 2-5, em fascículos axilares com os pedicelos superpostos verticalmente, mais raramente racemos ou dicásios. Cálice aberto no botão ou, em duas espécies, fechado e caindo como uma caliptra, sépalas 4, persistentes; bractéolas persistentes freqüentemente até o fruto maduro, raramente decíduas na antese; hipanto geralmente não prolongado sobre o ovário; anteras com deiscência longitudinal; ovário (2-)3(-4)locular, geralmente com muitos óvulos por lóculo, dispostos em duas fileiras longitudinais, placentação axilar. Bagas com sépalas persistentes; sementes 1-5, testa membranácea; embrião mircióide.

Myrceugenia é um gênero com cerca de 40 espécies, concentradas na América do Sul. Ocorrem especialmente no Brasil subtropical, mas também no Uruguai, Paraguai, Argentina e Chile. No Brasil, ocorrem 29 espécies, que se distribuem desde Minas Gerais e sul de Goiás e Rio de Janeiro ao Rio Grande do Sul (Kawasaki 1984; Landrum \& Kawasaki 1997), sendo que a maioria das espécies concentrase no sul do país.

O gênero foi tratado por Kausel (1942), Legrand (1958) e Landrum (1981). Ao contrário dos demais gêneros de Myrciinae, Myrceugenia possui ovário frequientemente 3-locular, com muitos óvulos por lóculo e flores nunca reunidas em panículas, apresentando-se geralmente solitárias ou em fascículos axilares, com pedicelos superpostos e bractéolas persistentes. No entanto, apresenta embrião mircióide, motivo pelo qual tem sido incluído em tal subtribo. 


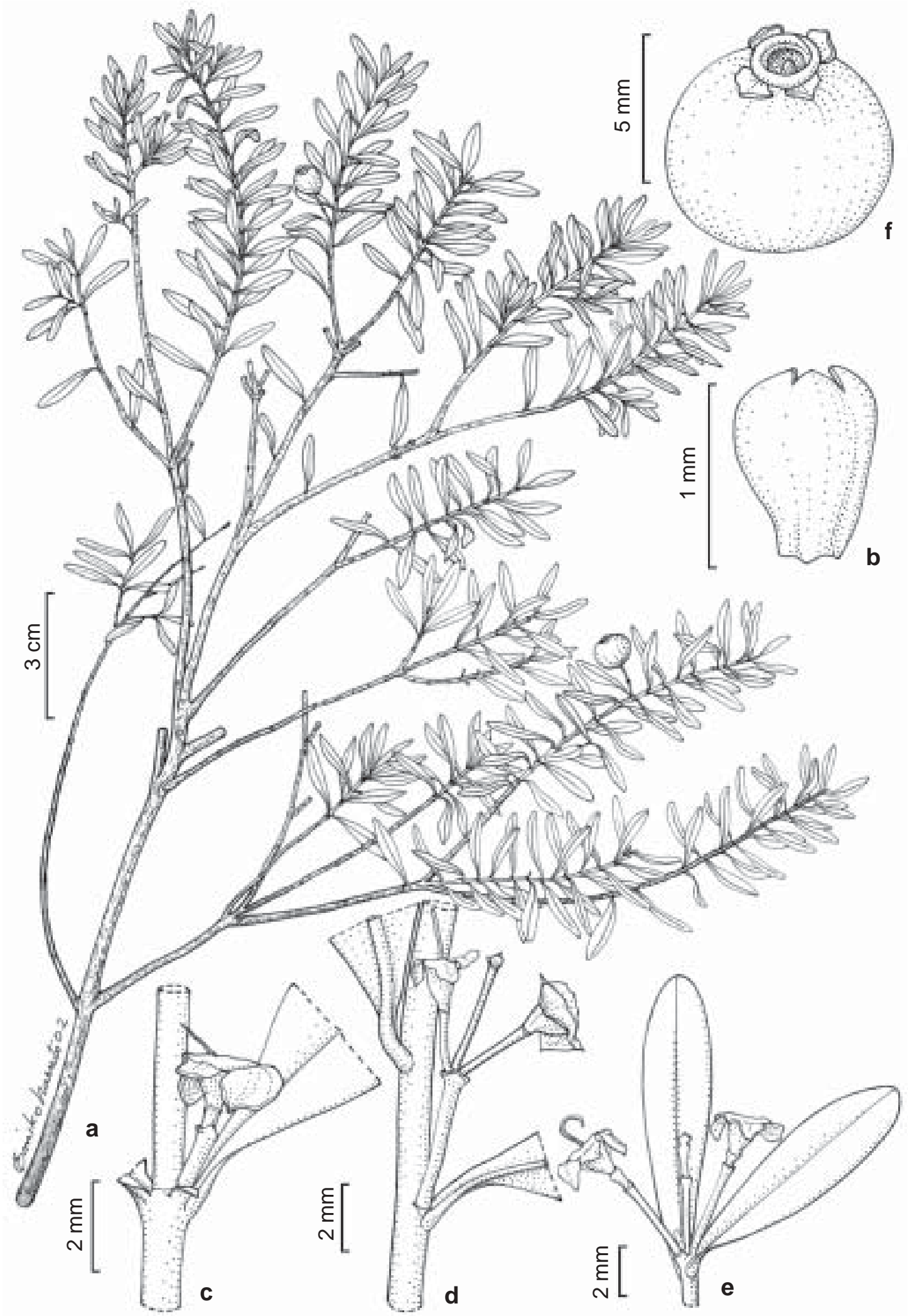

Figura 3 - Marlierea angustifolia - a. ramo com frutos; b. botão floral; c. ramo com flor solitária; d. ramo com cimeira 3-flora; e. ramo com fascículos com 3 flores; f. fruto. (a, f Mazine 152; b Mazine 158; c-e Souza 23229) 


\section{Chave para identificação das espécies de Myrceugenia}

1. Pedicelos 1,3-2 cm compr.; botões 6-8 $\mathrm{mm}$ compr., densamente tomentosos na região do hipanto e do cálice; sépalas 3-5 mm compr., densamente tomentosas na face externa; ovário 3-4-locular; bractéolas 3-5 mm compr. M. alpigena

1'. Pedicelos 0,4-1 cm compr.; botões 2-4 mm compr., densamente pubescentes na região do hipanto e esparsamente pubescentes na região do cálice; sépalas $0,5-1,5(-3) \mathrm{mm}$ compr., subglabras a esparsamente pubescentes na face externa; ovário 2-locular; bractéolas 1-1,5 $(-3,5)$ mm compr. M. ovata

5. Myrceugenia alpigena (DC.) Landrum, Brittonia 32(3): 372. $1980 . \quad$ Fig. 4 c-d Arbustos ou subarbustos 0,8-2 m alt., ramos densamente tomentosos tricomas alvos, amarelos ou ferrugíneos. Folhas com pecíolo de 2-4 mm compr.; lâminas discolores, geralmente elípticas, raramente elíptico-lanceoladas, 1,2-2,8 $\times 0,4-1,7 \mathrm{~cm}$, coriáceas, densamente tomentosas em ambas as faces quando jovens e glabras a pubérulas na face adaxial quando adultas e glabras a esparsamente tomentosas na face abaxial, tricomas alvos, amarelos ou ferrugíneos; ápice agudo e apiculado; base aguda; margem plana; nervura central sulcada na face adaxial e saliente na face abaxial; nervuras secundárias em número de 7-12 pares, indistintas ou salientes na face adaxial e salientes na face abaxial; nervura marginal simples, muitas vezes indistinta, a menos que $0,5 \mathrm{~mm}$ da margem; pontuações impressas, planas ou indistintas na face adaxial e salientes na face abaxial. Flores solitárias, geralmente duas por nó foliar, axilares, pedicelos 1,3-2 cm compr., densamente tomentosos. Botões 6-8 mm, densamente tomentosos na região do hipanto e do cálice, tricomas castanhos; bractéolas 3-5 mm compr., lanceoladas, persistentes; sépalas 3-5 mm compr., ovais a triangulares, densamente tomentosas na face externa; ovário 3-4-locular. Bagas globosas, ca. 5 mm diâm., esparsa a muito densamente tomentosas, negras, com indumento esbranquiçado, superfície lisa.

Distribuição geográfica: no Brasil, ocorre desde Minas Gerais e Goiás até o Rio Grande do Sul (Landrum 1981; Soares-Silva 2000). Foi encontrada em áreas de campo de altitude, próximo ao Pico da Bandeira, na região da Macieira, no Vale Encantado e próximo à Casa Queimada, sendo uma das espécies mais coletadas no Parque Nacional do Caparaó.
Material examinado: BRASIL. ESPÍRITO SANTO: Dores do Rio Preto, Parque Nacional do Caparaó, 19.X.1999, fr., F. F. Mazine et al. 181 (CESJ, ESA); Iúna, Parque Nacional do Caparaó, 18.II.2000, bt., V. C. Souza et al. 23331 (CESJ, ESA, GFJP); 18.II.2000, bt., V. C. Souza et al. 23333 (CESJ, ESA, GFJP); 18.II.2000, bt., fr., V. C. Souza et al. 23339 (ESA); s/ município, 'Serra do Caparaó', 3.III.1959, H. S. Irwin 2778 (R). MINAS GERAIS: Alto Caparaó, Parque Nacional do Caparaó, 20.III.1988, fl., R. F. Novelino et al. s.n. (CESJ 22225, ESA); IV.1989, fl., L. Krieger et al. s.n. (CESJ 24015, ESA); IV.1989, fl., L. Krieger et al. s.n. (CESJ 24074, ESA); 29.IX.1995, fr., L. S. Leoni et al. 3078 (GFJP); 12.II.1996, fl., L.S. Leoni 3199 (GFJP); I.1998, fl., L. S. Leoni 3865 (ESA, GFJP); 12.II.1998, fr., J. P. Souza et al. 2114 (ESA, GFJP); 12.II.1998, fl., J. P. Souza et al. 2122 (ESA); 17.VIII.1999, fr., F. F. Mazine et al. 155 (ESA); 17.II.2000, fl., V.C. Souza et al. 23318(CESJ,ESA, GFJP); 18.II.2000, bt., V.C. Souza et al. 23434 (CESJ, ESA, GFJP); 18.II.2000, bt., V. C. Souza et al. 23435 (CESJ, ESA, GFJP); 19.II.2000, fr., V. C. Souza et al. 23442 (ESA); Espera Feliz, Parque Nacional do Caparaó, 7.I.1999, fl., L. S. Leoni 4085 (ESA, GFJP); s/município, 'campos de Caparaó', 18-22.II.1915, Zikan s.n. (R 121348); s/ município, 'Serra do Caparaó', 15.XI.1941, fl., H. E. Strang 225 (RB); 28.VI.1950, N. Santos \& I. Campos s.n. (R 52147); 29.II.1960, fl., W. N. Vidal 97 (R).

Material adicional: BRASIL. MINAS GERAIS: Alto Caparaó, Parque Nacional do Caparaó, 17.VIII.1999, fr., F. F. Mazine et al. 159 (ESA, ICN).

Landrum (1981) considerou três variedades para $M$. alpigena, distintas pelo tamanho e indumento da face abaxial das folhas e pelo formato dos lobos do cálice. Os materiais do Parque Nacional do Caparaó correspondem a M. alpigena var. alpigena por terem folhas menores que $5 \mathrm{~cm}$, pubescentes na face abaxial (pelo menos quando jovens) e lobos do cálice agudos. Landrum (1981) citou que essa variedade foi principalmente encontrada em Itatiaia e na 




Figura 4 - a-b. Myrceugenia ovata - a. ramo com flores; b. botão floral. c-d. M. alpigena - c. ovário em corte transversal; d. embrião. (a Leoni 4066; b Leoni 3796; c Souza 23318; d Mazine 181) 
Serra dos Órgãos (RJ), em elevações acima de 2.000 m e no Pico da Bandeira (ES), em elevação semelhante, além de Guaratuba (PR) e Garuva (SC) a 1.200-1.350 m. Este mesmo autor referiu ainda que $M$. alpigena var. alpigena está relacionada a hábitats frios e úmidos.

6. Myrceugenia ovata (Hook. \& Arn.) O. Berg, Linnaea 30: 670. $1860 . \quad$ Fig. 4 a-b

Subarbustos a árvores (0,4-) 1,7-5 m alt., ramos jovens esparsa a muito densamente pubescentes, tricomas ferrugíneos. Folhas com pecíolo de 1,5-4 mm compr.; lâminas discolores, geralmente elípticas, às vezes estreitamente elípticas, $0,7-3 \times 0,3-1,2 \mathrm{~cm}$, coriáceas, glabras a subglabras na face adaxial e subglabras a muito densamente pubescentes na face abaxial; ápice agudo a agudo-atenuado; base aguda; margem plana; nervura central sulcada na face adaxial e saliente na face abaxial; nervuras secundárias em número de 6-9 pares, indistintas em ambas as faces ou indistintas na face adaxial e salientes na face abaxial; pontuações evidentemente impressas na face adaxial e salientes na face abaxial. Flores solitárias, geralmente duas por nó foliar, axilares, pedicelos $0,4-1 \mathrm{~cm}$, esparsa a densamente pubescentes. Botões $2-4 \mathrm{~mm}$ compr., densamente pubescentes na região do hipanto e esparsamente pubescentes na região do cálice; bractéolas 1-1,5 $(-3,5) \mathrm{mm}$ compr., oval-lanceoladas a lineares, persistentes; sépalas $0,5-1,5(-3) \mathrm{mm}$ compr., ovais a triangulares, subglabras a esparsamente pubescentes na face externa; ovário 2-locular. Bagas globosas a oblongo-elipsóides, $0,3-1 \mathrm{~cm}$ diâm., esparsa a densamente pubescentes, negros, superfície lisa ou verrucosa.

Distribuição geográfica: encontrada desde Minas Gerais até o Rio Grande do Sul (Landrum 1981; Soares-Silva 2000). Foi coletada em áreas de campo de altitude, geralmente próximo a cursos d'água, em diversas localidades do Parque Nacional do Caparaó.

Material examinado: BRASIL. ESPÍRITO SANTO: Dores do Rio Preto, Parque Nacional do Caparaó, 19.X.1999, fr., F. F. Mazine et al. 180 (ESA). MINAS GERAIS: Alto Caparaó, Parque Nacional do Caparaó, 2.I.1993, fl., L. S. Leoni 2035(GFJP); 12.XII.1995, fl., L. S. Leoni 3149 (GFJP); XI.1997, fl., L. S. Leoni 3801 (ESA, GFJP); 24.XI.1998, bt., L. S. Leoni 4064 (ESA, GFJP);
19.II.2000, fl., V.C. Souza etal. 23443 (ESA); 19.II.2000, fr., V. C. Souza etal. 23485(CESJ,ESA, GFJP); 19.II.2000, fl., V. C. Souza etal. 23486(CESJ,ESA, GFJP); 19.II.2000, fl., V. C. Souza et al. 23487 (ESA); 20.II.2000, fl., V.C. Souza et al. 23532 (CESJ, ESA, GFJP).

Material adicional: BRASIL. ESPÍRITO SANTO: Iúna, Parque Nacional do Caparaó, 18.II.2000, fr., $V$. C. Souza et al. 23423 (CESJ, ESA, GFJP). MINAS GERAIS: Alto Caparaó, Parque Nacional do Caparaó, XI.1997, fl., L. S. Leoni 3796 (GFJP); 24.XI.1998, fl., L. S. Leoni 4066 (ESA, GFJP); 17.VIII.1999, fr., F. F. Mazine et al. 151 (ESA, ICN).

Landrum(1981) considerou quatro variedades para Myrceugenia ovata, sendo que apenas duas ocorrem no Brasil. As quatro variedades distinguem-se pelo número de flores por nó, presença de brácteas, formato e dimensões das folhas, indumento dos ramos, comprimento das sépalas e do hipanto e número de óvulos por lóculo. Os materiais do Parque Nacional do Caparaó correspondem a M. ovata var. gracilis (Burret) Landrum por possuírem pedicelos não bracteados, folhas com geralmente mais de $1 \mathrm{~cm}$ compr., geralmente elípticas, lobos do cálice menores que $1,5 \mathrm{~mm}$ compr., hipanto geralmente menor que $1 \mathrm{~mm}$ compr. e menos de 6 óvulos por lóculo. Landrum (1981) referiu ainda que tal variedade possui pedicelos solitários, com apenas uma flor por nó. No entanto, os materiais do Parque Nacional do Caparaó apresentam pedicelos aos pares, ou seja, duas flores por nó, estado de caráter observado por Landrum (1981) apenas para $M$. ovata var. acutata (D. Legrand) Landrum. Além disso, os materiais do Caparaó apresentam ramos esparsa a densamente pubescentes. Segundo Landrum (1981), M. ovata var. acutata possui ramos moderadamente pubescentes a glabros, enquanto em $M$. ovata var. gracilis varia de esparsa a densamente pubescente, o que evidencia que as variedades reconhecidas por Landrum (1981) são frágeis taxonomicamente.

Myrcia DC. ex Guill. in J. B. G. Bory de Saint Vincent, Dict. Class. Hist. Nat. 11: 401. 1827.

Subarbustos, arbustos ou árvores; tricomas simples ou dibraquiados. Panículas ou cimeiras, raramente paucifloras ou racemosas ou reduzidas a dicásios tri- ou unifloros. Cálice aberto no botão, sépalas 5 , raramente 4 , 
persistentes, distintas; bractéolas geralmente decíduas; hipanto prolongado ou não acima do ovário; anteras com sacos polínicos dispostos na mesma altura, com deiscência longitudinal; ovário 2-3(-4)-locular, com 2 óvulos por lóculo, placentação axilar. Bagas com sépalas persistentes; sementes com testa membranácea ou cartilaginosa; embrião mircióide.
O gênero apresenta mais de 400 espécies distribuídas nas Américas tropical e subtropical, concentradas especialmente nas Regiões Centro-oeste e Sudeste do Brasil (McVaugh 1968, 1969; Kawasaki 1984). De acordo com Legrand \& Klein (1969), os campos cerrados de Minas Gerais corresponderiam à região com maior número de espécies.

\section{Chave para identificação das espécies de Myrcia}

1. Pedúnculo e raque da inflorescência glabros ....

M. obovata

1'. Pedúnculo e raque da inflorescência densamente pubescentes.

2. Ramificação marcadamente dicotômica; lâminas elíptico-oblongas ou elíptico-orbiculares; base das lâminas arredondada ou subcordada; ovário 2-locular M. subcordata

2'. Ramificação não dicotômica; lâminas geralmente obovais, elíptico-obovais, ou às vezes elípticas; base das lâminas atenuada; ovário 3-locular M. venulosa

7. Myrcia obovata (O. Berg) Nied., in H. G. A. Engler \& K. A. E. Prantl., Nat. Pflanzenfam. 3 (7): 76.1893.

Fig. $5 \mathrm{c}$

Arbusto ou árvore até $3 \mathrm{~m}$ alt.; ramos glabros, às vezes subglabros quando jovens. Folhas com pecíolo de 4-5 mm compr.; lâminas discolores, obovais a suborbiculares, 2,8-6 $\times$ $2-4,1 \mathrm{~cm}$, coriáceas, glabras em ambas as faces, às vezes pubérulas ao longo da nervura central na face abaxial; ápice arredondado a retuso; base aguda; margem plana; nervura central levemente sulcada na face adaxial e saliente na face abaxial; nervuras secundárias em número de 8-14 pares, salientes em ambas as faces; nervura marginal dupla, a 1-2 mm da margem; pontuações salientes em ambas as faces. Panículas extraaxilares, flores reunidas 3 a 3 , sésseis; pedúnculo 2-2,7 cm compr., glabro; raque glabra. Botões 2-4 mm compr., glabros; bractéolas ca. 1,5 mm compr., linear-lanceoladas, decíduas; sépalas com ápice arredondado, ca. $1 \mathrm{~mm}$ compr., glabras com margem ciliada, persistentes; ovário 3-locular. Bagas globosas, 4-5 mm diâm., subglabras, vermelhas; superfície lisa, com glândulas bem evidentes.

Distribuição geográfica: ocorre na Bahia, em Minas Gerais, São Paulo e Paraná (Peron 1994). Material examinado: BRASIL. MINAS GERAIS: Alto Caparaó, Parque Nacional do Caparaó, 21.II.2000, V. C. Souza et al. 23604 (ESA); s/ município, Parque Nacional do Caparaó, 3.IX.1970, bt.,A. B. Souza 81 (RB).
Material adicional: BRASIL. MINAS GERAIS: Alto Caparaó, Parque Nacional do Caparaó, VII.1997, fl., L. S. Leoni 3731 (ESA, GFJP).

Pode ser distinta das demais espécies de Myrcia ocorrentes no Parque pelos pedúnculos e inflorescências glabros.

Esta espécie foi referida por Kawasaki (1989) como Myrcia crassifolia Kiaersk. Entretanto, este nome é baseado em Eugenia crassifolia Miq. (publicado em 1847), que é um nome ilegítimojáquejá existia previamente o nome Eugenia crassifolia DC., publicado em 1828. Visto que a prioridade de Myrcia crassifolia corresponde ao ano de 1893 (McNeill et al. 2006), considerou-se o nome Myrcia obovata (baseada em Aulomyrcia obovata, publicada em 1855) para esta espécie. Oreconhecimento destes nomes como sinônimos tem sido adotado pela maioria dos autores, incluindo Berg (1857) e Peron (1994).

8. Myrcia subcordata DC., Prodr. 3: 253. 1828.

Fig. 5 a-b

Arbusto ou árvore 1,6-6 m alt.; ramos adultos glabros, jovens densamente pubescentes, ramificação marcadamente dicotômica, tricomas ferrugíneo-castanhos ou acinzentados. Folhas com pecíolo de 2-3 mm compr.; lâminas discolores, geralmente elíptico-oblongas ou elíptico-orbiculares, $4,2-6,2 \times 2,2-4,2 \mathrm{~cm}$, coriáceas, glabras a pubérulas, às vezes densamente ao longo da 
nervura central na face adaxial e glabras a densamente pubescentes na face abaxial quando adultas, subglabras a densamente pubescentes na face adaxial e muito densamente pubescentes na face abaxial quando jovens; ápice arredondado ou obtuso; base arredondada ou subcordada; margem plana; nervura central sulcada a saliente na face adaxial e saliente na face abaxial; nervuras secundárias em número de 8-14 pares, salientes em ambas as faces; nervura marginal dupla, a 2 $3 \mathrm{~mm}$ da margem; pontuações geralmente indistintas em ambas as faces, às vezes salientes na face abaxial. Panículas axilares, multifloras; pedúnculo 3-3,5 cm compr., muito densamente pubescente; raque densamente pubescente; tricomas ferrugíneos. Botões 3-4 mm compr., densamente pubescentes; bractéolas ca. $1 \mathrm{~mm}$ compr, oval-lanceoladas, decíduas; sépalas , $1 \mathrm{~mm}$ compr., com ápice arredondado, densamente pubescentes, persistentes; ovário 2-locular. Bagas globosas 4-7 mm diâm., pubérulas, muito densamente pubescentes próximo ao cálice, vináceas; superfície lisa, às vezes com glândulas evidentes.

Distribuição geográfica: segundo Peron (1994), M. subcordata é típica de afloramentos quartzíticos e matas ciliares dos campos rupestres, até então referida apenas para o estado de Minas Gerais. No Parque Nacional do Caparaó, esta espécie foi coletada no Vale Encantado, ao lado do manancial hídrico e na trilha para o Pico da Bandeira, em campo de altitude, a $2.300 \mathrm{~m}$ alt. Material examinado: BRASIL. MINAS GERAIS: Alto Caparaó, Parque Nacional do Caparaó, 20.X.1999, fr., F. F. Mazine et al. 216(ESA); 4.XI.1999, fr., L. S. Leoni 4279 (GFJP); s/ município, Parque Nacional do Caparaó, 12.III.1917, fl., bt., A. Lutz 1240 (R); s/ município, "Serra do Caparaó”, 9.IX.1941, fr., A. C. Brade 16895 (RB).

Material adicional: BRASIL. MINAS GERAIS: Alto Caparaó, Parque Nacional do Caparaó, 25.I.1997, fl., L. S. Leoni 3614 (GFJP).

Como características importantes para a distinção da espécie podem ser citadas: ramificação marcadamente dicotômica, base das folhas arredondada a subcordada, além do pedúnculo e raque da inflorescência densamente pubescentes.
9. Myrcia venulosa DC., Prodr. 3: 250. 1828.

Fig. $5 \mathrm{~d}$

Arbusto a arvoreta, 1,7-3 m alt.; ramos adultos subglabros, jovens esparsa a densamente pubescentes, ramificação não dicotômica, tricomas ferrugíneos, às vezes acinzentados. Folhas com pecíolo de 3-6 mm compr.; lâminas às vezes discolores, geralmente obovais, elípticoobovais, ou às vezes elípticas, $2,8-4 \times 1,1-2,1 \mathrm{~cm}$, coriáceas, esparsa a densamente pubescentes, raramente glabras na face adaxial, muito densamente pubescentes na face abaxial quando jovens, subglabras a esparsamente pubérulas, frequientemente densamente pubescentes ao longo da nervura central na face adaxial e subglabras a densamente pubescentes na face abaxial quando adultas; ápice agudo a arredondado, às vezes retuso; base atenuada; margem plana; nervura central saliente em ambas as faces; nervuras secundárias em número de 9-12 pares, salientes em ambas as faces; nervura marginal simples, a 1-1,5 mm da margem; pontuações indistintas ou salientes na face adaxial e salientes na face abaxial. Panículas axilares ou terminais, multifloras, pedúnculo 1,7-3,5 cm, muito densamente pubescente; raque densamente pubescente. Botões 2-4 mm compr., pubérulos, mas pubescentes na região do hipanto; bractéolas ca. 1,5 mm compr., linear-lanceoladas, decíduas; sépalas ca. $1 \mathrm{~mm}$ compr., ápice agudo a arredondado, subglabras com margem ciliada; ovário 3-locular. Bagas globosas, 3-4 mm diâm., glabras a subglabras, avermelhadas; superfície lisa, às vezes com glândulas evidentes.

Distribuição geográfica: ocorre desde Goiás, Bahia e Rio de Janeiro até o Rio Grande do Sul (Soares-Silva 2000; Lughadha 1995; Proença 1994; Peron 1994), sendo encontrada em diversas localidades do Parque Nacional do Caparaó, em beira de mata e campos de altitude.

Material examinado: BRASIL. ESPÍRITO SANTO: Dores do Rio Preto, Parque Nacional do Caparaó, 19.X.1999, bt., F. F. Mazine et al. 182 (ESA). MINAS GERAIS: Alto Caparaó, Parque Nacional do Caparaó, 6.IX.1977, bt., G. J Shepherd et al. 5809 (UEC); 12.XII.1995, fl., L. S. Leoni3152 (ESA, GFJP); 24.XI.1998, fl., L. S. Leoni 4061 (ESA, GFJP); XII.1998, fl., L. S. Leoni 4068 (ESA, GFJP); XII.1998, fl., L. S. Leoni 4069 


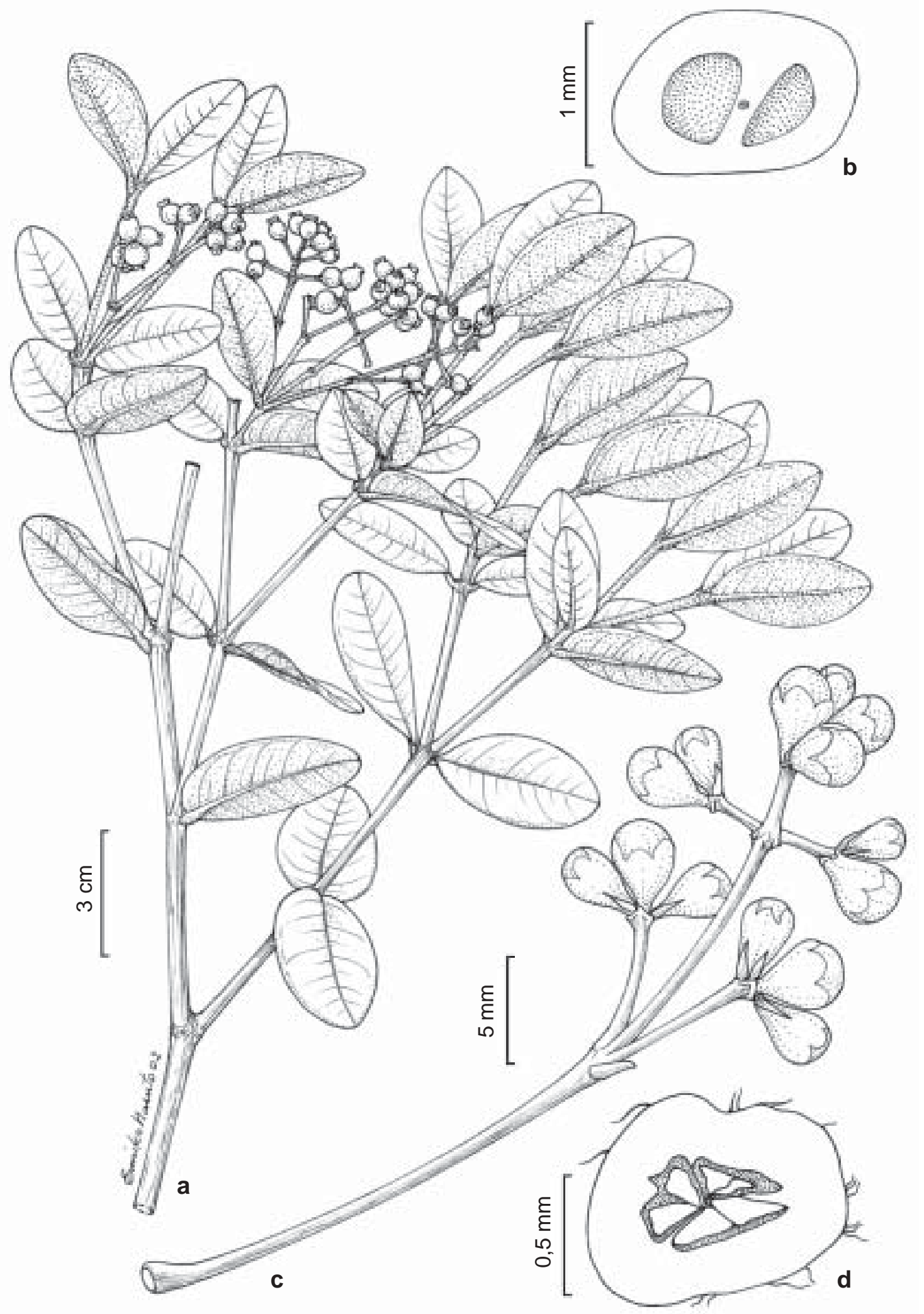

Figura 5 - a-b. Myrcia subcordata - a. ramo com frutos; b. ovário em corte transversal. c. M. obovata - c. inflorescência. d. M. venulosa - d. ovário em corte transversal. (a Mazine 216; b Lutz 1240; c Leoni 3731; d Leoni 4069) 
(ESA, GFJP); 20.X.1999, bt., F. F. Mazine et al. 214 (ESA, ICN);21.II.2000, fr., V. C. Souza et al. 23626(ESA). Material adicional: BRASIL. MINAS GERAIS: Alto Caparaó, Parque Nacional do Caparaó, I.1998, fr., L. S. Leoni 3859 (ESA, GFJP); XII.1998, L. S. Leoni 4068, fl. (ESA, GFJP).

Myrcia venulosa possui geralmente folhas obovais, com indumento variando de glabro a densamente pubescente. Suas inflorescências (raque e pedicelos) são sempre densamente pubescentes, o que pode ser utilizado para diferenciá-la de M. guianensis (Aubl.) DC., espécie com a qual se assemelha. McVaugh (1969) citou M. guianensis como uma espécie de ampla distribuição geográfica, composta por uma série de populações regionais desde o norte da Venezuela e ilhas próximas, leste dos Andes e Bolívia até o sudeste do Brasil.

Peron (1994) e Kawasaki (1984) apontaram que $M$. venulosa apresenta grande variação em sua morfologia foliar e na coloração do indumento, o que não foi constatado entre as populações do Parque Nacional do Caparaó.

\section{Pimenta Lindl., Coll. Bot.: t. 19. 1821.}

Arbustos ou árvores, tricomas simples. Dicásios ou panículas de 3-15 flores. Cálice aberto no botão, sépalas 4, geralmente persistentes; bractéolas decíduas; hipanto não prolongado; estames com anteras com deiscência longitudinal; ovário 2-locular, 3-6óvulos por lóculo, placentação subapical. Bagas com cálice persistente; sementes geralmente 1 ou 2, com testa cartilaginosa; embrião mirtóide.

Pimenta conta com 15 espécies, das quais apenas uma, Pimenta pseudocaryophyllus, possui representantes na flora brasileira, em especial nas Regiões Sul e Sudeste do Brasil. As demais espécies são nativas do Caribe (Landrum \& Kawasaki 1997).

Segundo a chave de gêneros apresentada por Landrum \& Kawasaki (1997), o gênero Pimenta é distinto dos demais gêneros de Myrtinae principalmente pelas inflorescências em dicásios ou panículas, pelo cálice aberto no botão, 4-mero e persistente. No entanto, Landrum (1986), aponta flores 4- ou 5-meras, além da existência de uma espécie com cálice totalmente fechado no botão, rompendo-se irregularmente na antese e decíduo antes da maturação do fruto. Landrum (1986), no entanto, não é explícito quanto aos critérios utilizados por ele para delimitação do gênero em relação aos demais gêneros da subtribo Myrtinae. Pimenta e Blepharocalyx, por exemplo, segundo Landrum \& Kawasaki (1997), parecem estar delimitados pela persistência do cálice no fruto em Pimenta (geralmente, pois em uma espécie é decíduo), enquanto em Blepharocalyx o cálice é decíduo (geralmente, pois das 3 espécies, uma - do Chile - é persistente, as outras duas são decíduas), deixando uma cicatriz quadrangular no fruto. Legrand \& Klein (1978) também referiram Blepharocalyx como tendo 4 sépalas, decíduas na antese.

10. Pimenta pseudocaryophyllus (Gomes) Landrum, Brittonia 36(3): 242. 1984.

Fig. $1 \mathrm{a}-\mathrm{b}$

Árvore, ramos glabros a pubérulos. Folhas com pecíolo 9-12 mm compr.; lâminas discolores, elípticas a elíptico-oblongas, 8,2-12×3,6-5 cm, coriáceas, glabras na face adaxial e seríceas na face abaxial, com tricomas prateados; ápice agudo a levemente acuminado; base aguda; margem plana; nervura central sulcada na face adaxial e saliente na face abaxial; nervuras secundárias em número de 13-17 pares, salientes em ambas as faces; nervura marginal simples, a 1-2 $\mathrm{mm}$ da margem; pontuações planas na face adaxial e salientes na face abaxial. Flores não vistas (Landrum 1986: dicásios ou panículas dicasiais; 3-15 flores; pedúnculos até $6 \mathrm{~cm}$ compr., esparsa a densamente cobertas com tricomas, depois glabrescentes. Bractéolas ca. 1-3 mm compr., lineares a estreitamente lanceoladas, decíduas antes da antese; sépalas 1-2 mm ovais a hemiorbiculares, fortemente côncavas, densamente a esparsamente pubescentes, tomentosas ou glabras; ovário 2-locular). Bagas globosas, 8-9 mm diâm., glabros a subglabros; superfície lisa.

Distribuição geográfica: Landrum (1986) referiu que a espécie é encontrada no Sudeste e Sul do Brasil, desde Minas Gerais e Goiás até Santa Catarina, além de uma população 
na Bolívia. Barroso \& Peron (1994) referiram ainda que a espécie ocorre na Bahia.

Material examinado: BRASIL. MINAS GERAIS: s/ município, "Serra do Caparaó", 17.IX.1941, fr., A. C. Brade 16942 (RB).

Pimenta pseudocaryophyllus é separada por Landrum (1986) em três variedades, distintas principalmente pelo indumento, formato, dimensões e ápice das folhas. O material coletado no Parque Nacional do Caparaó pertence à variedade Pimenta pseudocaryophyllus var. pseudocaryophyllus, por possuir folhas elípticas, com indumento seríceo e prateado na face abaxial e ápice agudo. Landrum (1986) citou que para tal variedade a largura das folhas não deveria exceder $3,6 \mathrm{~cm}$; no entanto, as folhas do material coletado no Parque possuem 3,6-5 cm de largura.

A variedade Pimenta pseudocaryophyllus var. pseudocaryophyllus é citada por Landrum (1986) como sendo uma pequena árvore típica de áreas florestais nas terras altas do sudeste do Brasil. No entanto, a única coleta desse material no Parque Nacional do Caparaó (em 1941), foi feita nos campos de altitude. Não se descarta a possibilidade de que tenha havido um erro de anotação na etiqueta de coleta do material. Tal material foi referido por Landrum (1986) em sua monografia do gênero Pimenta para a Flora Neotropica. Landrum (1986) referiu, ainda, que os extremos das três variedades regionais são prontamente distinguíveis, mas que existem numerosos intermediários, especialmente nas montanhas da costa do Rio de Janeiro até Santa Catarina.

\section{Agradecimentos}

Os autores expressam sinceros agradecimentos a CAPES, pela bolsa concedida à primeira autora no período de abril de $2001 \mathrm{a}$ junho de 2002; à Direção do Parque Nacional do Caparaó, pelo apoio e pela infra-estrutura oferecida; ao pesquisador Lúcio de Sousa Leoni, curador do herbário GFJP, pelo companheirismo nas viagens de coleta, pelo atendimento à solicitação de pedido de material e por nos apresentar o Parque Nacional do Caparaó; ao pesquisador Marcos Sobral, pelas sugestões e pelo fornecimento de dados de algumas espécies.

\section{REFERÊNCIAS BIBLIOGRÁFICAS}

Barroso, G. M.; Peixoto, A. L.; Costa, C. G.; Ichaso, C. L. \& Lima, H. C. 1984. Myrtaceae. Sistemática das Angiospermas do Brasil. v.2. Ed. Univ. Fed. Viçosa, Viçosa, 377p. \& Peron, M. 1994. Myrtaceae. In: Lima, M. P. M. \& Guedes-Bruni, R. R. (ed.). Reserva Ecológica de Macaé de Cima, Nova Friburgo-RJ. Aspectos florísticos das espécies vasculares. v.1. Jardim Botânico do Rio de Janeiro, Rio de Janeiro. Pp. 259-302.

\& Peixoto, A. L. 1995. Myrtaceae da Reserva Florestal de Linhares, Espírito Santo, Brasil - Gêneros Calyptranthes e Marlierea. Boletim do Museu de Biologia Mello Leitão (N. Sér.) 3: 3-38.

Berg, O. 1857. Myrtaceae. In: Martius, C. F. P. Flora brasiliensis 14(1): 1-468.

Cronquist, A. 1981. An integrated system of classification of flowering plants. New York Botanical Garden, Columbia University Press, New York. Pp. 639-642.

Dubs, B. 1998. The Botany of Mato Grosso: Prodromus Florae Matogrossensis. Betrona, Verlag.

Heywood, V. H. 1979. Flowering plants of the world. Oxford University Press, London. Pp. 161-162.

Hickey, M. \& King, C. 1988. 100 Families of flowering plants. Pp. 232-235.

Holmgren, P. K.; Holmgren, N. H. \& Barnett, L. C. 1990. Index Herbariorum. Part 1: The herbaria of the world. $8^{\text {th }}$ ed. New York Botanical Garden, 693p.

Holst, B. K.; Landrum, L. \& Grifo, F. 2003. Myrtaceae. In: Berry, P. E.; Yatskievych, K. \& Holst, B. (eds). Flora of the Venezuelan Guayana. v. 7. Missouri Botanical Garden Press. Pp. 1-99.

IBDF. 1981. Plano de Manejo para o Parque Nacional do Caparaó. Fundação Brasileira para a Conservação da Natureza. Doc. Tec. n. 8. Brasília, 139p.

Kausel, E. 1942. Contribución al estudio de las Mirtáceas chilenas. Revista Argentina de Agronomia 11:320-327. 
Kawasaki, M. L. 1984. A família Myrtaceae na Serra do Cipó, Minas Gerais, Brasil. Dissertação de Mestrado. Universidade de São Paulo, São Paulo, 202p.

. 1989. Flora da Serra do Cipó, MG,

Brasil: Myrtaceae. Boletim de Botânica da Universidade de São Paulo 11: 121-170. . 2000. Flora Fanerogâmica do Parque Estadual das Fontes do Ipiranga (São Paulo, Brasil): Myrtaceae. Hoehnea 27(2): 165-186. \&Holst, B. K. 2004. Myrtaceae. In: Smith, N.; Mori, S. A.; Henderson, A.; Stevenson, D. W. \& Heald, S. V. (eds.). Flowering plants of the New Tropics. The New York Botanic Garden \& Princeton University Press, Princeton \& Oxford. Pp. 264-266.

Landrum, L. R. 1981. A monograph of the genus Myrceugenia (Myrtaceae). Flora Neotropica 29: 1-137.

. 1986. Campomanesia, Pimenta, Blepharocalyx, Legrandia, Acca, Myrrhinium and Luma (Myrtaceae). Flora Neotropica 45: 1-179.

\& Kawasaki, M. L. 1997. The genera of Myrtaceae in Brazil: an illustrated synoptic treatment and identification keys. Brittonia 49(4): 508-536.

Legrand, C. D. 1958. Las especies neotropicales del género Gomidesia. Comunicaciones Botánicas del Museo de Historia Natural de Montevideo 3(37): 1-30.

. 1962. Sinopsis de las especies de Marlierea del Brasil. Comunicaciones Botánicas del Museo de Historia Natural de Montevideo 3(40): 1-39.

\& Klein, R. M. 1967. Gomidesia Berg.

(Fasc. Mirt.). In: Reitz, R. Flora Ilustrada Catarinense. Pp. 3-44. $\&$ 1969. Myrcia DC. (Fasc. Mirt.). In: Reitz, R. Flora Ilustrada Catarinense. Pp. 219-330. $\&$ 1978. Myrciaria, Pseudocaryophyllus, espécies suplementares, espécies cultivadas, generalidades (Fasc. Mirt.). In: Reitz, R. Flora Ilustrada Catarinense. Pp. 733-876.
Leitão-Filho, H. F. 1993. Ecologia da Mata Atlântica de Cubatão (São Paulo). Editora Unesp, São Paulo, 184p.

Leoni, L. S. 1997. Catálogo preliminar das fanerógamas ocorrentes no Parque Nacional do Caparaó - MG. Pabstia 8(2): 1-28.

\& Souza, V. C. 1999. Espécies endêmicas ocorrentes no Parque Nacional do CaparaóMinas Gerais. Pabstia 10(1): 1-14.

Lughadha, E. 1995. Myrtaceae. In: Stannard, B. L. (ed.). Flora of the Pico das Almas. Royal Botanic Gardens, Kew. Pp. 492-517. \& Snow, N. 2000. Biology and Evolution of the Myrtaceae: A Symposium. Kew Bulletin 55: 591-592.

Mattos, J. R. 1967. Novidades taxonômicas em Marlierea (Myrtaceae). Ciência e Cultura 19 (2): 333.

McNeill, J.; Barrie, F. R.; Burdet, H. M.; Demoulin, V.; Hawksworth, D. L.; Marhold, K.; Nicolson, D. H.; Prado, J.; Silva, P. C.; Skog, J. E.; Wiersema, J. H. \& Turland, N. J. 2006. International Code of Botanical Nomenclature (Vienna Code). Regnum Veg. Pp. 100.

McVaugh, R. 1968. The genera of American Myrtaceae - an interim report. Taxon 17: 354-418.

1969. Myrtaceae. The botany of the Guayana Highland - pt. 8. Memoirs of the New York Botanical Garden 18(2): 55-286.

Peron, M. V. 1994. O gênero Myrcia DC. coletado no Município de Ouro Preto, Minas Gerais, Brasil. Daphne 4(2): 8-28.

Proença, C. 1994. Listagem Comprovada das Myrtaceae do Jardim Botânico de Brasília "Check-List". Boletim do Herbário Ezechias Paulo Heringer 1: 9-26.

Reitz, R.; Klein, R. M. \& Reis, A. 1978. Projecto Madeira de Santa Catarina. Sellowia 28-30.

Soares-Silva, L. H. 2000. A família Myrtaceae subtribos Myrciinae e Eugeniinae na bacia hidrográfica do Rio Tibagi, estado do Paraná, Brasil. Tese de Doutorado. Universidade Estadual de Campinas, Campinas, 462p. 